\title{
Hidradenoma Papilliferum of the Caruncle
}

\section{Hind M Alkatan ${ }^{1 *}$, Patricia Akaishi ${ }^{2,3}$ and Antonio AV Cruz ${ }^{2,3,4}$}

${ }^{1}$ Department of Pathology and Laboratory Medicine, King Khaled Eye Specialist Hospital, Riyadh, Saudi Arabia

${ }^{2}$ Oculoplastics and Orbit Division, King Khaled Eye Specialist Hospital, Riyadh, Saudi Arabia

${ }^{3}$ Department of Ophthalmology, Otorhinolaryngology and Head and Neck Surgery, School of Medicine of RibeirãoPreto-University of São Paulo, Brazil

${ }^{4}$ Wilmer Eye Institute, Johns Hopkins University, Baltimore, Maryland, USA

\begin{abstract}
Hidradenoma papilliferum (HAP) is known since the nineteen century. The vast majority of cases occur on genital and perianal regions of women. Tumors found in other areas of the body are considered to be "ectopic".

The lacrimal caruncle is a vestigial skin structure with a diverse histology including hair. To our knowledge, the presence of HAP on the caruncle was referred only once in a series of cases published in a gynecological journal. We report for the first time in the ophthalmic literature a case of a caruncular hidradenoma papilliferum (HAP) as an unusual benign tumor of apocrinic differentiation.
\end{abstract}

Keywords: Caruncle; Apocrine; Hidradenoma

\section{Introduction}

The human skin has 3 to 4 million sweat glands distributed over most of the body surface. Most of these glands are eccrinic which control body temperature by releasing their hypotonic secretion directly on the skin surface without any cell loss [1]. However, apocrine sweat glands, are larger than eccrine glands and secrete, by focal apical decapitation, a proteinaceous viscous sweat into a hair canal. They are concentrated on the axilla, the areola of nipple and genital and perianal areas [1]. The lacrimal caruncle is a vestigial skin structure with a diverse histology including hair [2]. We report for the first time in the ophthalmic literature a case of Caruncular Hidradenoma Papilliferum (HAP), an unusual benign tumor of apocrinic differentiation.

\section{Case Report}

A 69 year-old female was referred to the oculoplastic service for an atypical enlargement of the right caruncle. The patient denied any trauma or pain and stated that she first noticed the abnormal size of the caruncle 2 months prior to presentation. On examination there was a round $8.0 \times 4.0 \mathrm{~mm}$, reddish and firm mass on the right caruncle (Figure 1). The remaining ophthalmic evaluation was unremarkable. Complete surgical excision was performed under local anesthesia without complications and the specimen was sent for histopathological analysis.

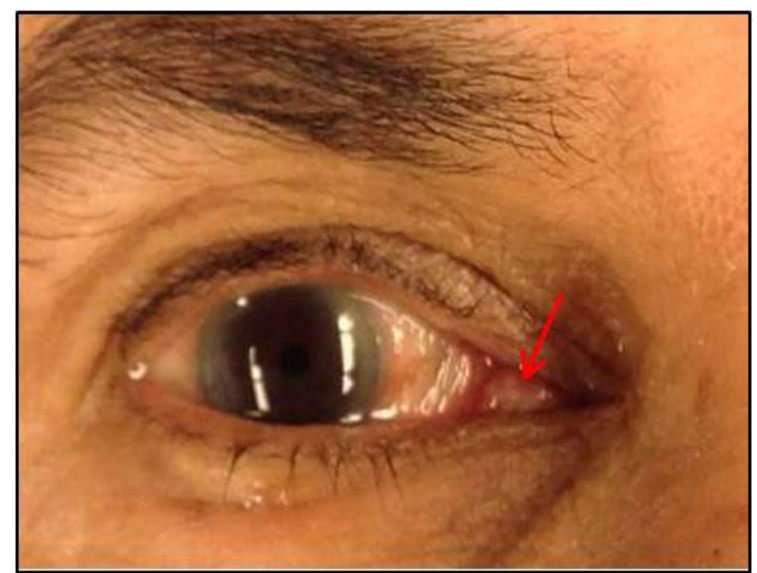

Figure 1: The clinical appearance of the right eye caruncular mass (red arrow)
Microscopic examination revealed a soft tissue lesion without connection to the overlying epithelium. The nodule showed tubules and elongated fronds with an arborizing pattern lined by double-layered epithelium. The inner layer was composed of cuboidal cells and the outer layer was tall and consisted of columnar apocrine cells. Periodic acid-Schiff (PAS) -positive diastase-resistant granules were present in the apices of these cells. The mass showed pseudo capsule and cystic areas with colloidal iron positive material. In focal areas infiltration by lymphocytes and plasma cells was observed. The epithelial lesion was positive with cytokeratin CK7 and Epithelial Membrane Antigen (EMA) stains. The inner myoepithelial layer was positive with smooth muscle actin (SMA) and p63 confirming apocrine origin; however the cytoplasmic gross-cystic disease fluid protein-15 stain (GCDP-15) was negative. The mitotic index using Ki 67 was low (Figures 2a-2f).

\section{Discussion}

According to Meeker et al. [3], who reviewed the literature on HAP in 1962, this peculiar adenoma is known since the nineteen century. The vast majority of cases occur on genital and perianal regions of women. Tumors found in other areas of the body are considered to be "ectopic" [4]. The head and neck region is the most common site of non-genital HAP [4] As the gland of Molls are modified apocrinic glands, it is not surprising that some cases of HAP related to the eye were reported on the eyelids [5-7] or eyebrow [8,9]. As the orbit has no sweat glands we believe that the only one true ectopic HAP was the orbital lesion recently reported [10]. Although the presence of sweat gland cysts have been found on the caruncle $[11,12]$, HAP did not appear among the 1136 caruncular lesions described in the major series on pathology of the caruncle published in the English literature [11-16]. To our knowledge, the presence of HAP on the caruncle was referred only once on a series of cases published in a gynecological journal [17]. HAP is a benign tumor and does not recur if completely excised. Clinically it presents as an inconspicuous solitary nodule of varying size. The diagnosis is

*Corresponding author: Hind M Alkatan, Department of Pathology and Laboratory Medicine, King Khaled Eye Specialist Hospital, Riyadh, Saudi Arabia, Tel: 011-4821234; E-mail: hindkatan@yahoo.com

Received April 04, 2015; Accepted April 21, 2015; Published April 24, 2015

Citation: Alkatan HM, Akaishi P, Cruz AAV (2015) Hidradenoma Papilliferum of the Caruncle. J Clin Case Rep 5: 513. doi:10.4172/2165-7920.1000513

Copyright: (C 2015 Alkatan HM, et al. This is an open-access article distributed under the terms of the Creative Commons Attribution License, which permits unrestricted use, distribution, and reproduction in any medium, provided the original author and source are credited. 


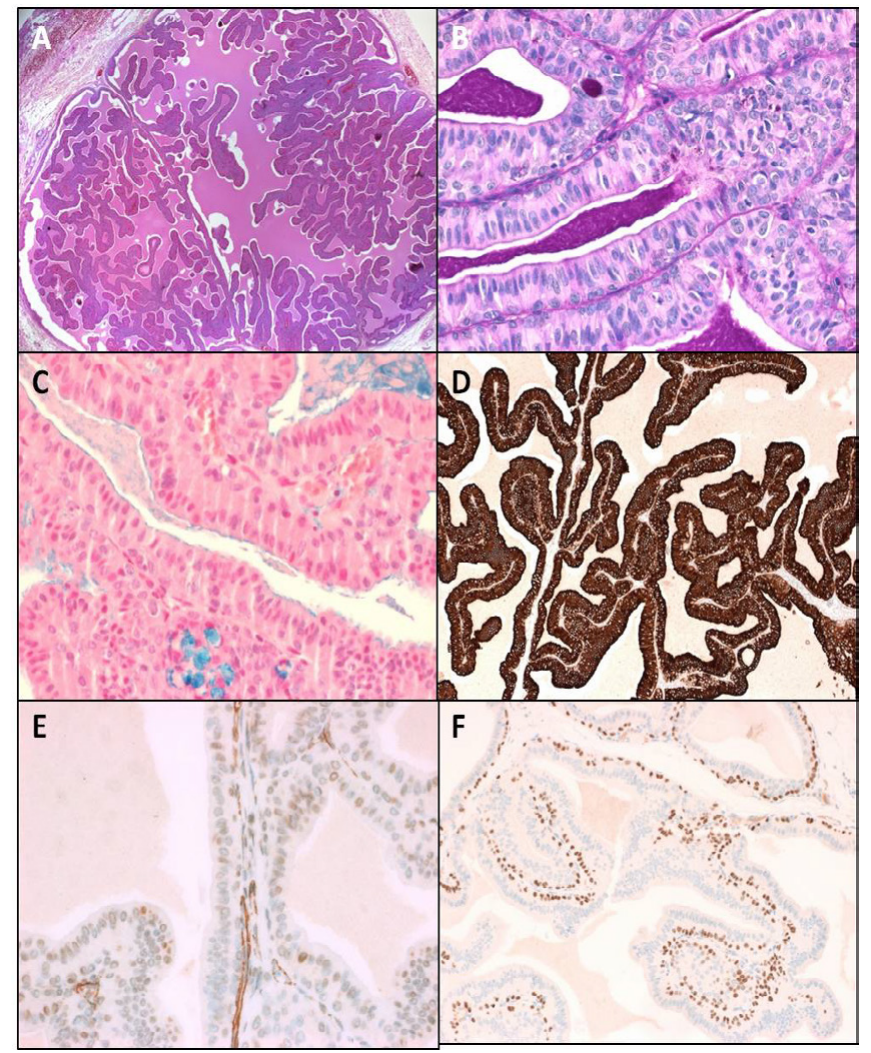

Figure 2: (A)The histopathologic appearance of the well demarcated lesion (Original magnification 25x, hematoxylin and eosin), (B) Higher power picture showing the columnar cells with diastase-resistant secretory granules (Original magnification 400x, periodic acid Schiff), (C) Cystic areas with colloidal iron positive material (Original magnification 400x), (D) The epithelial lesion stained positive with Cytokeratin stain (Original magnification 100x, CK7), (E) The myoepithelial basal layer stained with smooth muscle actin (Original magnification 200x, SMA), (F) Nuclear staining of the myoepithelial basal cells with p63 (Original magnification 400x).

entirely dependent on the microscopic features of the tumor since it is a variant of apocrine adenoma with peculiar morphology. Usually the tumor is partly cystic with papillary and glandular components as described in our typical case. Immunohistochemical staining is helpful in confirming the diagnosis specially in highlighting the myoepithelial cell layer using SMA, p63 and GCDP-15 stains. The presence of this myoepithelial cell layer and the secretory granules are important distinguishing features between apocrine and eccrine lesions [6]. The mitotic index in HAP is variable; however it does not necessarily reflect the aggressive behavior, which is seen in hidradenocarcinoma.

Although the rate of malignant transformation of HAP is considered to be low [6], wide local excision is the treatment modality of choice, especially for lesions located intimately on the medial canthus, a notoriously difficult region to perform surgery.

\section{References}

1. Sato K, Kang WH, Saga K, Sato KT. Biology of sweat glands and their disorders. I. Normal sweat gland function. J Am Acad Dermatol 20: 537-63.

2. Bron AJ, Tripathi RJ, Tripathi BJ (1997) The ocular appendages: eyelids conjunctiva and lacrimal apparatus. In: Wolff's Anatomy of the Eye and Orbit $\left(8^{\text {th }}\right.$ edn $)$, Chapman \& Hall Medical, London, UK.

3. Meeker JH, Neubecker RD, Helwig EB (1962) Hidradenoma papilliferum. Am J Clin Pathol 37: 182-195.

4. Vang R, Cohen PR (1999) Ectopic Hidradenoma Papilliferum: a case report and review of the literature. J Am Acad Dermatol 41: 115-118.

5. Jain D, Siraj F, Grover AK, Garg KK (2012) Hidradenoma Papilliferum presenting as an eyelid mass. Ophthal Plast Reconstr Surg 28: e152-153.

6. Jakobiec FA, Rai R, Lefebvre DR (2014) Papillary hidradenoma of the eyelid margin: clinical and immunohistochemical observations further supporting an apocrine rather than an eccrineorigin. Surv Ophthalmol 59: 540-547.

7. Santa Cruz DJ, Prioleau PG, Smith ME (1981) Hidradenoma Papilliferum of the eyelid. Arch Dermatol 117: 55-56.

8. Al-Faky YH, Al-Mosallam AR, Al-Sohaibani MO (2009) Periocular hidradenoma papilliferum. Saudi J Ophthalmol 23: 211-213.

9. Rosmaninho AD, de Almeida MT, Costa V, Sanches MM, Lopes C, et al. (2010) Ectopic hidradenoma papilliferum.. Dermatol Res Pract 2010: 709371.

10. Katz SE, Collins AB, Peters SB (2013) Hidradenoma papilliferum of the orbit Orbit 32: 49-50.

11. Kaeser PF, Uffer S, Zografos L, Hamédani M (2006) Tumors of the caruncle: a clinicopathologic correlation. Am J Ophthalmol 142: 448-455.

12. Luthra CL, Doxanas MT, Green WR (1978) Lesions of the caruncle: a clinicohistopathologic study. Surv Ophthalmol 23: 183-195.

13. Levy J, Ilsar M, Deckel Y, Maly A, Pe'er J (2009) Lesions of the caruncle: a description of 42 cases and a review of the literature. Eye (Lond) 23: 10041018.

14. Ostergaard J, Prause JU, Heegaard S (2006) Caruncular lesions in Denmark 1978-2002: a histopathological study with correlation to clinical referral diagnosis. Acta Ophthalmol Scand 84: 130-136.

15. Shields CL, Shields JA, White D, Augsburger JJ (1986) Types and frequency of lesions of the caruncle. Am J Ophthalmol 102: 771-778.

16. Santos A, Gómez-Leal A (1994) Lesions of the lacrimal caruncle. Clinicopathologic features. Ophthalmology 101: 943-949.

17. Ioannides G (1966) Hidradenoma papilliferum. Am J ObstetGynecol 94: 849853. 